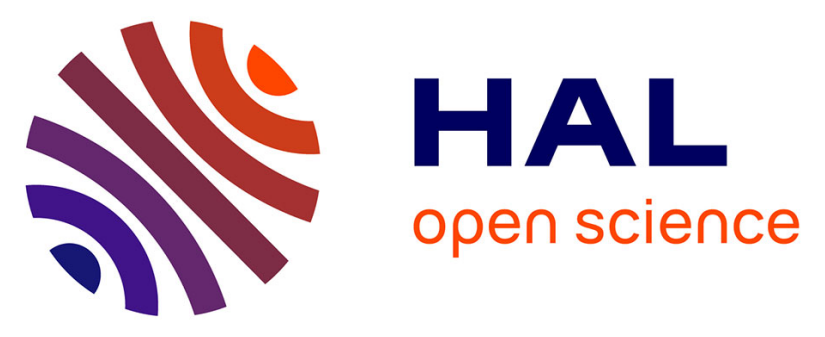

\title{
Laparoscopic insemination method in sheep allows the use of an animal protein-free and inexpensive freezing medium
}

\author{
Lucie Gavin-Plagne, Lionel Boyer, Anne Baudot, Magda Guedes Teixeira, \\ Gérard Louis, Loris Commin, S. Buff, Thierry Joly
}

\section{To cite this version:}

Lucie Gavin-Plagne, Lionel Boyer, Anne Baudot, Magda Guedes Teixeira, Gérard Louis, et al.. Laparoscopic insemination method in sheep allows the use of an animal protein-free and inexpensive freezing medium. Annual Conference of the International Embryo Technology Society, Jan 2020, New York, United States. Reproduction, Fertility and Development, 32 (2), pp.206, 2020, 10.1071/RDv32n2Ab159 . hal-02450391

\section{HAL Id: hal-02450391 \\ https://hal-vetagro-sup.archives-ouvertes.fr/hal-02450391}

Submitted on 22 Jan 2020

HAL is a multi-disciplinary open access archive for the deposit and dissemination of scientific research documents, whether they are published or not. The documents may come from teaching and research institutions in France or abroad, or from public or private research centers.
L'archive ouverte pluridisciplinaire HAL, est destinée au dépôt et à la diffusion de documents scientifiques de niveau recherche, publiés ou non, émanant des établissements d'enseignement et de recherche français ou étrangers, des laboratoires publics ou privés. 
